\title{
Medico-ethnobotany of Magar Community in Salija VDC of Parbat District, Central Nepal
}

\author{
Shubhechchha Thapa \\ Central Department of Environmental Science, Tribhuvan University \\ E-mail: shubek@gmail.com
}

\begin{abstract}
This paper documents the ethno-medicinal use of plant species among the Magar community of Salija Village Development Committee from Parbat District in the central mid-hills of Nepal. The study recorded the use of 75 species of medicinal plants belonging to 46 families and 72 genera for the treatment of 39 different ailments. The most frequently treated illness were gastrointestinal ailments followed by dermatological infection and skeleto-muscular problem. Local healers and the knowledgeable groups were the one who mostly make use of medicinal plant species. The traditional home remedy is less practiced compared to the past years, and also lacks the sharing of knowledge among the practitioners. Documenting such herbal folklore knowledge is useful for further pharmaceutical research.
\end{abstract}

Key words: Medicinal plants, Ethnomedicine, Magars, Traditional healers

\section{Introduction}

Nepal has been regarded as the natural showroom of biodiversity, and such biodiversity has supported the livelihood of people, particularly for those who live in remote areas (Magar, 2008). Their myths and rituals, as well as their traditional environmental practices, portray a close relation between human beings and nature. The local people traditionally acquired diversity of knowledge regarding the utilization of plant resources for various purposes such as food, clothing, construction, ritual performances, energy, and most importantly for medicinal purposes. About $80-90 \%$ people living in rural areas of Nepal depends, directly or indirectly, on traditional medicinal practices and about $85 \%$ of such practices involves the use of plants extracts (Bhattarai, 1992). These medicinal plant species have been considered as an important source of potentially therapeutic drugs (Cox and
Ballick, 1994). Worldwide, more than 21,000 plant species have been recorded that acquires medicinal values (Shrestha et al., 2000). In Nepal, at least 1600 to 1900 species of medicinal plants are used in traditional medicinal practices (Tiwari, 1994; Baral and Kurmi, 2006).

Nepal is a multi-ethnic nation with diverse languages, religions and cultural traditions. There are more than 100 caste/ethnic groups speaking 92 languages and 124 dialects (CBS, 2001). The entire ethnic groups have their own culture, tradition and way of living. Magars are one of the aborigines of Nepal with 1,622,421 population comprising $7.1 \%$ of the total population (CBS, 2001) that accounts for the most populated indigenous group and third most populated ethnic/caste group of Nepal. They are the Mongolian people having Mongoloid physical features with well proportioned facial contours and 
yellowish colour (Bista, 2004). The Magar people have their own mother tongue, which is originated from Tibeto-Burman family. So, their language is influenced by Tibetan dialect (Gautam and Thapa-Magar, 1994). The original home of the Magars was called Bara Magarath, the 12 region of Magars, which included all the Hill Districts of Lumbini, Rapti and Bheri Zones. However, now, they have spread all along the Hills of west Nepal, and to a few places in eastern Terai (Gautam and Thapa-Magar, 1994).

The Magars are traditionally farmers, and inhabit the area near the forest, forest patches, and forest boundary (Magar, 2008). So, they are closely linked with nature and have rich knowledge, skills and techniques on the traditional utilization of natural resources, especially the locally found plant species for traditional healing purposes. The present paper documents the plant species used by the Magar community for local medicinal purposes.

\section{Materials and methods}

\section{Study area}

The study was conducted in Salija Village Development Committee (VDC) of Parbat District in central Nepal (Fig. 1). It is located at an altitude ranging from 1600 to $3000 \mathrm{~m}$ above sea level, with an area of about $16 \mathrm{sq} . \mathrm{km}$. The climate of the area is sub-temperate where the temperature varies from $0^{\circ} \mathrm{C}$ to $28^{\circ} \mathrm{C}$, and there is snowfall in some of the hills during the winter. The total population of the village was 2993 and the Magars are the most dominant ethnic group having the population of 1854 that comprises $61.94 \%$ of the total population (DDP, 2004).

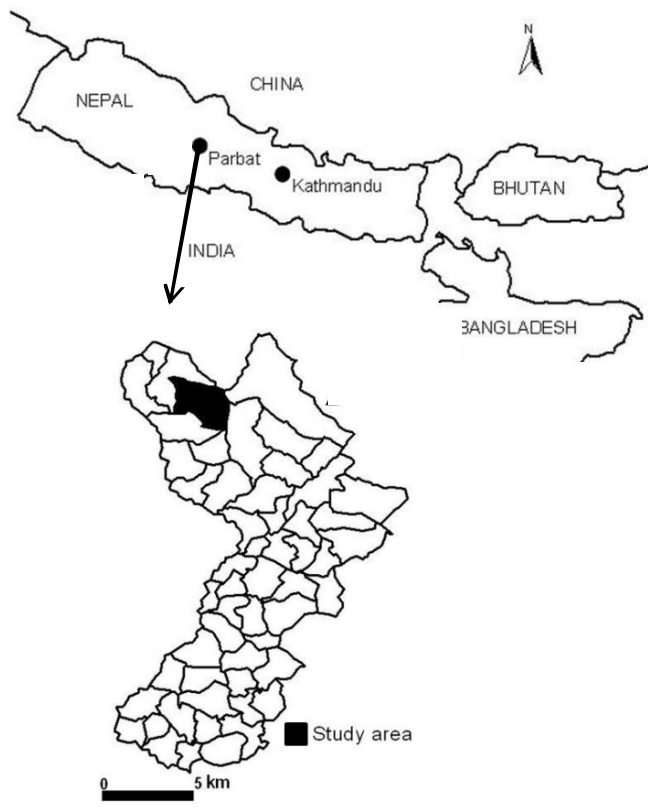

Figure 1. Geographical location of the study area

\section{Data collection}

The study was carried out from September 2007 through March 2008. Regular field visit was conducted during this period of time. By using purposive or judgment (non-probability) sampling method, the sample of 40 resource persons was selected that includes local healers (Dhami/Jhankri), knowledgeable elder people, community leaders, VDC chairperson, forest ranger, medicinal plant collectors, school teachers as well as youths and local people from the study area. Focus group discussion and key informant interview were conducted in order to obtain the detailed information about the plants used in herbal medicine. Prior informed consent was obtained before beginning each interview.

Voucher specimens of the collected plant species was prepared following the standard methods (Lawrence, 1967; Martin, 1995), and identified with standard 
literatures (Malla et al., 1976; Polunin and Stainton, 1984; Mani, 1994), and with the help of botanists from the Central Department of Botany (TU) and the National Herbarium and Plant Laboratories Godawari, Nepal.

\section{Results and discussion}

\section{Plant diversity}

The Magar community of the study area makes use of 75 species of medicinal plant belonging to 46 families and 72 genera for the treatment of different ailments by using their own indigenous knowledge (Tab. 1). Based on the life form of those species, herbs representing $56 \%$ of the plant species were the primary source of medicinal plants followed by trees $(21 \%)$ and shrubs (12\%) (Fig. 2). The dominant use of herbaceous plant for ethno-medicinal purposes was also reported by Giday et al. (2009); Simbo (2010).

\section{Plant parts used}

Different parts of the plant, both dried and fresh, were used either in the raw form or through processing for local remedies (Fig. 3 ). Roots of the plant were used for higher number of remedies (22) followed by the leaves (14) and seeds (10). Higher proportion of ethno-medicinal practices from root sources was also reported by Lulekal et al. (2008), Bhattarai et al. (2010), and Cheikhyoussef et al. (2011).

\section{Types of diseases treated}

The recorded 75 medicinal plant species were used for the treatment of 39 different ailments/diseases (Tab. 2). The most commonly treated diseases were gastrointestinal ailments (mouth ulcer, gastritis, stomach pain, dysentery, cholera, constipation, intestinal worm) followed by dermatological infection (scabies, skin burn, skin boils, eczema, herpes zoster) and skeleto-muscular problem (swelling, body pain, back pain, dislocated bone/fracture, rheumatism). Most of the plant species were found to have more than a single therapeutic uses, and also the plants were either used singly or in combination, which sometimes includes animal species as well (Tab. 2). For instance, the mixture of honey and the juice of Amomum zingiber were used to cure cough and cold.

\section{Forms of medication}

The plant species were used in different forms such as juice, decoction, infusion, paste, powder, cooked and smoke. Sometimes, the fresh or dried plant parts were used in their raw or natural form. Juice was the most commonly used form of medication that comprises $34 \%$ of plant species followed by decoction (20\%), paste (13\%), and powder (10\%) (Fig. 4).

\section{Routes of administration}

Medical administration included oral, nasal and instillation, the internal medication, and topical, the external. However, about $65 \%$ of the medication were administrated orally (57 remedies) followed by topical (20 remedies) and nasal (4 remedies) (Fig. 5). Similar results were also reported in other ethno-medicinal studies (Lulekal et al., 2008; Bhattarai et al., 2010; Rana et al., 2010)

\section{Similar uses}

The reported ethno-medicinal practices of plant species in the present study have similar uses in other areas too. For instance, 
Shubhechchha Thapa / Our Nature (2012) 10: 176-190

Table 1. List of medicinal plants used by the Magar community in Salija VDC.

\begin{tabular}{|c|c|c|c|c|c|}
\hline $\mathbf{S} / \mathbf{N}$ & Family & Scientific name & Local name & Habit & Parts used \\
\hline 1 & Acanthaceae & Justicia adhatoda $\mathrm{L}$. & Asuro & Shrub & Leaf \\
\hline 2 & Amaranthaceae & Achyranthes bidentata $\mathrm{Bl}$. & Datiwan & Herb & Root, stem \\
\hline 3 & Amaranthaceae & Amaranthus spinosus L. & Lunde & Herb & Root \\
\hline 4 & Amaryllidaceae & Allium cepa $\mathrm{L}$. & Pyaz & Herb & Bulb \\
\hline 5 & Amaryllidaceae & Allium sativum $\mathrm{L}$. & Lasun & Herb & Bulb \\
\hline 6 & Anacard iaceae & Mangifera indica $\mathrm{L}$. & Amchura & Tree & Bark \\
\hline 7 & Anacard iaceae & Rhus semialata Murray & Bhaki amilo & Tree & Seed \\
\hline 8 & Araceae & Acorus calamus L. & Bojho & Herb & Rhizome \\
\hline 9 & Berberidaceae & Berberis asiatica Roxb. Ex DC & Chutro & Shrub & Bark \\
\hline 10 & Berberidaceae & Mahonia napaulensis DC & Jamane mandro & Shrub & Bark \\
\hline 11 & Caryophyllaceae & Drymaria cordata $\mathrm{L}$. & Abijaalo & Herb & Whole plant \\
\hline 12 & Compositae & Artemesia indica Willd. & Tite pati & Herb & Leaf \\
\hline 13 & Compositae & $\begin{array}{l}\text { Eupatorium adenophorum } \\
\text { Spreng. }\end{array}$ & Banmaara & Herb & Leaf \\
\hline 14 & Compositae & $\begin{array}{l}\text { Inula cappa (Buch.-Ham. ex D. } \\
\text { Don) DC }\end{array}$ & Bakhrikane jhar & Herb & Root \\
\hline 15 & Convolvulaceae & Cuscuta reflexa Roxb. & Aakash beli & Herb & $\begin{array}{l}\text { Whole } \\
\text { plant, root }\end{array}$ \\
\hline 16 & Cruciferae & Lepidium sativum $\mathrm{L}$. & Chamsur & Herb & Seed \\
\hline 17 & Cucurbitaceae & $\begin{array}{l}\text { Solena amplexicaulis (Lam.) } \\
\text { Gandhi }\end{array}$ & Gol kaankri & Climber & Root \\
\hline 18 & Dryopteridaceae & $\begin{array}{l}\text { Tectaria coadunata (Wall. ex. J. } \\
\text { Sm.) C.Chr. }\end{array}$ & Kalo niuro & Fern & Rhizome \\
\hline 19 & Equisetaceae & $\begin{array}{l}\text { Equisetum debile Roxb. ex } \\
\text { Vaucher }\end{array}$ & Kurkure & Herb & Root \\
\hline 20 & Ericaceae & Lyonia ovalifolia (Wall.) Drude & Angeri & Shrub & Shoot \\
\hline 21 & Ericaceae & Rhododendron arboreum Smith & Laaligurans & Tree & Flower \\
\hline 22 & Euphorbiaceae & Emblica officinalis Gaertn. & Aamala & Tree & Bark, fruit \\
\hline 23 & Euphorbiaceae & Euphorbia hirta L. & Dudhe jhar & Herb & Root \\
\hline 24 & Gentianaceae & $\begin{array}{l}\text { Swertia nervosa (G. Don) C.B. } \\
\text { Clarke }\end{array}$ & Tite & Herb & Whole plant \\
\hline 25 & Geraniaceae & $\begin{array}{l}\text { Geranium wallichianum D. Don } \\
\text { ex Sweet }\end{array}$ & Rakalaamul & Herb & Root \\
\hline 26 & Hypoxidaceae & Curculingo orchioides Gaertn. & Museli & Herb & Root \\
\hline 27 & Labiatae & Mentha spicata L. & Pudina & Herb & Leaf \\
\hline 28 & Labiatae & Ocimum sanctum $\mathrm{L}$. & Tulsi maa & Herb & Leaf \\
\hline 29 & Lauraceae & Cinnamomum zeylanicum BL. & Dalchini & Tree & Seed \\
\hline 30 & Lauraceae & $\begin{array}{l}\text { Lindera neesiana (Wall. ex Ness) } \\
\text { Kurz }\end{array}$ & Siltimur & Tree & Seed \\
\hline 31 & Leguminosae & Bauhinia variegata $\mathrm{L}$. & Koiralo & Tree & Bark \\
\hline 32 & Leguminosae & Trigonella foenum-graceum $\mathrm{L}$. & Methi & Herb & Seed \\
\hline
\end{tabular}


Shubhechchha Thapa / Our Nature (2012) 10: 176-190

\begin{tabular}{|c|c|c|c|c|}
\hline Liliaceae & Asparagus racemosus Willd. & Kurilo & Climber & Root \\
\hline Liliaceae & Paris polyphylla Smith & Satuwaa/Bajuro & Herb & $\begin{array}{l}\text { Rhizome, } \\
\text { shoot }\end{array}$ \\
\hline Lycopodiaceae & Lycopodium clavatum $\mathrm{L}$. & Naagbeli & Fern & Root \\
\hline Lythraceae & Woodfordia fruticosa (L.) Kurz & Dhaero & Shrub & Flower \\
\hline Malvaceae & Hibiscus lampas Cav. & Ban kapaas & Shrub & Root \\
\hline Menispermaceae & Cissampelos pariera $\mathrm{L}$. & Gujargano & Climber & Root \\
\hline Moraceae & $\begin{array}{l}\text { Ficus semicordata Buch.-Ham. } \\
\text { ex Sm. }\end{array}$ & Khanyu & Tree & Leaf \\
\hline Moraceae & Morus alba $\mathrm{L}$. & Kimkafal & Tree & Root \\
\hline Musaceae & Musa paradisiaca $\mathrm{L}$. & Keraa & Herb & Root \\
\hline Myricaceae & $\begin{array}{l}\text { Myrica esculenta Buch.-Ham. ex } \\
\text { D. Don }\end{array}$ & Kaaphal & Tree & Bark \\
\hline Myrtaceae & Psidium guajava $\mathrm{L}$. & Ambaa & Tree & Leaf \\
\hline Myrtaceae & $\begin{array}{l}\text { Syzygium operculatum (Roxb.) } \\
\text { Merril\& Perry }\end{array}$ & Kyaamun & Tree & Bark, leaf \\
\hline Oxalidaceae & Oxalis corniculata $\mathrm{L}$. & Chari amilo & Herb & Whole plant \\
\hline Pinaceae & Pinus roxburghii Sargent & Khote sallo & Tree & Resin \\
\hline Plantaginaceae & Plantago major $\mathrm{L}$. & Ishabgol & Herb & Seed \\
\hline Polygonaceae & Rheum australe D. Don & Padamchalnu & Herb & Root \\
\hline Polygonaceae & Rumex dentatus $\mathrm{L}$. & $\begin{array}{l}\text { Halhale, } \\
\text { Banpalungo }\end{array}$ & Herb & Root \\
\hline Pteridaceae & Cheilanthes dalhousiae Hook. & Raani sinkaa & Fern & Leaf (frond) \\
\hline Rosaceae & $\begin{array}{l}\text { Fragaria nubicola Lindl. ex } \\
\text { Lacaita }\end{array}$ & Bhuin ainselu & Herb & Fruit, leaf \\
\hline Rosaceae & Potentilla fulgens Wall. ex Hock & Bajradanti & Herb & Root \\
\hline Rosaceae & Prunus cerasoides D. Don & Painyu & Tree & Bark \\
\hline Rosaceae & Rubus ellipticus $\mathrm{Sm}$. & Ainselu & Shrub & Root, shoot \\
\hline Rubiaceae & Rubia manjith Roxb. Ex Fleming & Majitho & Herb & Whole plant \\
\hline Rutaceae & $\begin{array}{l}\text { Citrus aurantifolia (Christ.) } \\
\text { Swingle }\end{array}$ & Kaagati & Tree & Fruit \\
\hline Rutaceae & Zanthoxylum armatum DC. & Timur & Shrub & Seed, root \\
\hline Saxifragaceae & Bergenia ciliata (Haw.) Sternb. & Paakhanved & Herb & Stem, root \\
\hline Solanaceae & Solanum capsicoides All. & Kantakaari & Shrub & Fruit \\
\hline Taxaceae & Taxus wallichiana Zucc. & Lumit & Tree & Bark, leaf \\
\hline Tropaeolaceae & Tropaeolum majus $\mathrm{L}$. & Bharamase phul & Herb & Leaf, flower \\
\hline Umbelliferae & Anethum sowa Kurz. & Swoup & Herb & Seed \\
\hline Umbelliferae & Carum copticum C.B. Clarke & Jwaano & Herb & Seed \\
\hline Umbelliferae & Centella asiatica (L.) Urb. & Ghortaapre & Herb & Whole plant \\
\hline Umbelliferae & $\begin{array}{l}\text { Selinum wallichianum (DC.) } \\
\text { Raizada \& Saxena }\end{array}$ & Bhutkesh & Herb & Rhizome \\
\hline
\end{tabular}


Shubhechchha Thapa / Our Nature (2012) 10: 176-190

$\begin{array}{llllll}66 & \text { Urticaceae } & \text { Girardinia diversifolia }(\text { Link) } & \text { Chalne sisnoo } & \text { Herb } & \text { Root } \\ 67 & \text { Urticaceae } & \text { Gonostegia hirta }(\text { Bl.) Miquel } & \text { Chiple ghaans } & \text { Herb } & \text { Whole plant } \\ 68 & \text { Urticaceae } & \text { Urtica dioca } \text { L. } & \text { Sisnu } & \text { Herb } & \text { Leaf } \\ 69 & \text { Vitaceae } & \begin{array}{l}\text { Ampelocissus rugosa } \text { (Wall.) } \\ \text { Planch. }\end{array} & \text { Airi lahara } & \text { Climber } & \text { Whole plant } \\ 70 & \text { Vitaceae } & \begin{array}{l}\text { Tetrastigma serrulatum } \text { (Roxb.) } \\ \text { Planch. }\end{array} & \text { Charchare } & \text { Climber } & \text { Leaf } \\ 71 & \text { Zingiberaceae } & \text { Amomum subulatum } \text { Roxb. } & \text { Alaichi } & \text { Herb } & \text { Seed } \\ 72 & \text { Zingiberaceae } & \text { Amomum zingiber } \text { L. } & \text { Aduwa } & \text { Herb } & \text { Rhizome } \\ 73 & \text { Zingiberaceae } & \text { Curcuma } \text { caesia } \text { Roxb. } & \text { Kaalo haledo } & \text { Herb } & \text { Rhizome } \\ 74 & \text { Zingiberaceae } & \text { Curcuma longa } \text { auct. Non. L. } & \text { Besar } & \text { Herb } & \text { Rhizome } \\ 75 & \text { Zingiberaceae } & \text { Elettaria cardamomum }(\text { L. }) & \text { Sukumel } & \text { Herb } & \text { Fruit } \\ & & \text { Maton } & & \end{array}$

Table 2. Diseases/Ailments with the mode of treatment

\begin{tabular}{|c|c|c|c|c|}
\hline $\mathbf{S} / \mathbf{N}$ & $\begin{array}{l}\text { Diseases/ } \\
\text { Ailments }\end{array}$ & Plant species & $\begin{array}{l}\text { Forms of } \\
\text { medication }\end{array}$ & Mode of treatment \\
\hline 1 & Agalactia & Asparagus racemosus Willd. & Juice & $\begin{array}{l}\text { The juice from about } 50 \mathrm{gm} \text { roots of } A \text {. } \\
\text { racemosus is diluted with } 250 \mathrm{ml} \text { of water } \\
\text { and taken twice a day which increases the } \\
\text { lactation. }\end{array}$ \\
\hline 2 & Back pain & $\begin{array}{l}\text { Anethum sowa Kurz., Bergenia } \\
\text { ciliata (Haw.) Sternb., Curcuma } \\
\text { caesia Roxb., Lepidium sativum } \\
\text { L. }\end{array}$ & $\begin{array}{l}\text { Powder, } \\
\text { decoction }\end{array}$ & $\begin{array}{l}\text { The powder from } 10 \mathrm{gm} \text { seeds of } A \text {. sowa } \\
\text { and } L \text {. sativum, small amount of young } \\
\text { shoots of } B \text {. ciliate and } 5 \text { gm rhizome of } C \text {. } \\
\text { caesia is mixed with rice grain and cooked, } \\
\text { and then taken in the form of meal which } \\
\text { helps to cure the back pain. The decoction } \\
\text { from dried or fresh rhizome of } C \text {. caesia is } \\
\text { taken orally to get relief from the back } \\
\text { pain. }\end{array}$ \\
\hline 3 & $\begin{array}{l}\text { Blood } \\
\text { pressure }\end{array}$ & $\begin{array}{l}\text { Psidium guajava L., Swertia } \\
\text { nervosa (G. Don) C.B. Clarke }\end{array}$ & Decoction & $\begin{array}{l}\text { The decoction of leaves of } P \text {. guajava is } \\
\text { taken orally to control blood pressure. The } \\
\text { decoction of } S \text {. nervosa is useful for the } \\
\text { control of blood pressure. }\end{array}$ \\
\hline 4 & Body pain & $\begin{array}{l}\text { Bergenia ciliata (Haw.) Sternb., } \\
\text { Cissampelos pariera L., Rheum } \\
\text { australe D. Don }\end{array}$ & $\begin{array}{l}\text { Decoction, } \\
\text { powder }\end{array}$ & $\begin{array}{l}\text { The decoction extracted by boiling about } \\
50 \text { gm roots of } B \text {. ciliata in } 250 \mathrm{ml} \text { of } \\
\text { water for } 10-15 \text { minutes is taken orally to } \\
\text { reduce body pain. The decoction extracted } \\
\text { by boiling about } 100 \text { gm roots of } C \text {. } \\
\text { pariera in } 500 \mathrm{ml} \text { of water for } 15-20 \\
\text { minutes is drunk to get relief from body } \\
\text { pain. About } 20 \text { gm root powder of } R \text {. } \\
\text { australe is diluted with } 250 \mathrm{ml} \text { of water, } \\
\text { and then taken orally to ease body pain; } \\
\text { root decoction can also be used for it. }\end{array}$ \\
\hline 5 & Cholera & $\begin{array}{l}\text { Lindera neesiana (Wall. ex } \\
\text { Ness) Kurz }\end{array}$ & Powder & $\begin{array}{l}\text { Two teaspoons of seed powder of } L \text {. } \\
\text { neesiana are taken with water for the } \\
\text { treatment of cholera. }\end{array}$ \\
\hline
\end{tabular}


Shubhechchha Thapa / Our Nature (2012) 10: 176-190

6 Cold

Amomum subulatum Roxb., Amomum zingiber L., Acorus calamus $\mathrm{L}$. Constipatio
$\mathrm{n}$
Cough

Girardinia diversifolia (Link) Friis

8 Cough

Ocimum sanctum L., Amomum zingiber L., Acorus calamus L.

9 Cut and wound

Artemesia indica Willd., Eupatorium adenophorum Spreng., Euphorbia hirta L., Tetrastigma serrulatum (Roxb.) Planch., Prunus cerasoides D. Don, Pinus roxburghii Sargent, Lycopodium clavatum $\mathrm{L}$.

\section{Diabetes}

Urtica dioca $\mathrm{L}$.

11 Diarrhea Rhus semialata Murray

12 Dislocated Ampelocissus rugosa (Wall.) bone Planch.,Gonostegia hirta (Bl.) Miquel

13 Dysentery
Woodfordia fruticosa (L.) Kurz, Tectaria coadunata (Wall. ex. J. Sm.) C. Chr.,Rhododendron arboreum Smith, Myrica esculenta Buch.-Ham. ex D. Don
Decoction, Few gm seeds of $A$. subulatum along with juice, raw its cover is grinded and then boiled in 300 $\mathrm{ml}$ of water for 10-15 minutes and taken orally to get relief from cold. One teaspoon of rhizome juice of $A$. zingiber mixed with honey is taken orally to cure cold. Two teaspoons of rhizome juice of $A$. calamus is taken twice a day for the treatment of cold; the raw rhizome can also be chewed for it. In addition, the garland made from the sun dried rhizome of A. calamus is worn by the affected person to cure cold. Juice The juice from the root of G. diversifolia is drunk for the treatment of constipation.

Decoction, juice, raw

Juice, raw, Decoction

\section{Leaf decoction of $O$. sanctum is taken} regularly for cough. One teaspoon of rhizome juice of $A$. zingiber mixed with honey is taken orally to cure cough. Two teaspoons of rhizome juice of A. calamus is taken twice a day for the treatment of cough; the raw rhizome can also be chewed for it.

The fresh juice of leaves of $A$. indica, $E$. adenophorum, L. clavatum and $T$. serrulatum, and the fresh latex of roots of $E$. hirta is applied in the cut and wound for its fast recovery. About $100 \mathrm{gm}$ bark of $P$. cerasoides is boiled in one liter of water until it becomes half and then filtered, the filtrate or decoction is again boiled by adding some resin of $P$. roxburghi for 20-25 minutes, thus formed drug is then applied for the treatment of cut and wounds.

Cooked The leaves of U. dioca are cooked and taken daily for the treatment of diabetes.

Decoction The seed decoction of $R$. semialata is taken regularly to cure diarrhea.

Paste The paste of whole plant made from equal amount of A. rugosa and G. hirta is applied as a plaster supported by wood to set the dislocated bone.

Powder, A teaspoon powder of dried flower of $W$. fruticosa is taken with water to cure dysentery. Two teaspoons of rhizome juice of $T$. coadunata is taken twice a day to cure dysentery until it is cured. Two teaspoons of dried flower powder of $R$. arboreum is mixed with $120 \mathrm{ml}$ of water or curd and taken orally to cure dysentery. Two teaspoons of fresh bark juice of $M$. 
Shubhechchha Thapa / Our Nature (2012) 10: 176-190

14 Eczema

Amomum subulatum Roxb., Prunus cerasoides D. Don, Pinus roxburghii Sargent

Selinum wallichianum (DC.) Raizada \& Saxena, Paris polyphylla Smith

16 Eye boils

Allium cepa L., Berberis asiatica Roxb. Ex DC, Mahonia napaulensis DC

17 Fever

Swertia nervosa (G. Don) C.B. Clarke, Rubus ellipticus $\mathrm{Sm}$.

18 Fish bone prick

19 Gastritis

Rhododendron arboreum Smith

Allium sativum L., Asparagus
Paste, decoction

Smoke, juice

Juice, decoction (

Decoction, juice racemosus Willd., Bauhinia variegata $\mathrm{L} .$, Carum copticum C.B. Clarke, Cheilanthes dalhousiae Hook., Cissampelos pariera L., Curcuma longa auct. Non. L., Drymaria cordata L., Emblica officinalis Gaertn., Geranium wallichianum D. Don ex Sweet, Zanthoxylum armatum DC., Taxus wallichiana Zucc., Solena amplexicaulis (Lam.) Gandhi, Rubus ellipticus Sm., Psidium guajava L., Mangifera indica $\mathrm{L}$.

Roast, juice, powder, decoction esculenta is taken orally for the treatment of dysentery.

The paste from the seeds of $A$. subulatum is applied on the affected area to cure eczema. About $100 \mathrm{gm}$ bark of $P$. cerasoides is boiled in one liter of water until it becomes half and then filtered, the filtrate or decoction is again boiled by adding some resin of $P$. roxburghi for 20-25 minutes, thus formed drug is then applied for the treatment of eczema. The smoke from the rhizome of $S$. wallichianum is inhaled as well as the rhizome juice is taken orally for curing the illness due to evil spirit. The young shoots of the P. polyphylla that grows once in a year is also used for curing illness due to evil spirit.

Few drops of bulb juice of $A$. cepa are instilled for curing the eye boils. The decoction formed by boiling about $20 \mathrm{gm}$ bark of B. asiatica in $200 \mathrm{ml}$ of water for 10-15 minutes is used to cure eye boils. The decoction prepared by boiling $20 \mathrm{gm}$ bark of M. napaulensis in $200 \mathrm{ml}$ of water for 10-15 minutes is instilled to cure eye boils.

Two teaspoons of decoction made from the whole plant of $S$. nervosa is taken thrice a day for curing high fever; hot steam of decoction is also inhaled for it. The juice of young shoots of R. ellipticus is taken thrice a day for the treatment of high fever. The raw flower of $R$. arboreum is chewed and swallowed to release fish bone prick. Few pieces of the roasted bulb of $A$. sativum are taken orally to cure gastritis. Two teaspoons of root juice of $A$. racemosus taken orally twice a day helps to cure gastritis. The juice extracted from about each 50 gm fresh bark of $B$. variegata and $M$. indica along with few leaves of $P$. guajava is taken orally two-three times a day for curing gastritis. A teaspoon of powder made from $5 \mathrm{gm}$ seeds of $C$. copticum and few seeds of $Z$. armatum is taken orally with lukewarm water for treating gastritis. Two teaspoons of juice extracted from few leaves of $C$. dalhousiae and each $10 \mathrm{gm}$ roots of $R$. ellipticus and G. wallichianum is taken 
Shubhechchha Thapa / Our Nature (2012) 10: 176-190

\begin{tabular}{|c|c|c|c|}
\hline 20 & $\begin{array}{l}\text { Gum } \\
\text { swelling }\end{array}$ & Rumex dentatus L. & Raw \\
\hline 21 & Headache & $\begin{array}{l}\text { Lindera neesiana (Wall. ex } \\
\text { Ness) Kurz }\end{array}$ & Paste \\
\hline 22 & $\begin{array}{l}\text { Herpes } \\
\text { zoster }\end{array}$ & $\begin{array}{l}\text { Fragaria nubicola Lindl. ex } \\
\text { Lacaita }\end{array}$ & Paste \\
\hline 23 & $\begin{array}{l}\text { In } \\
\text { appetence } \\
\text { due to evil } \\
\text { eyes }\end{array}$ & Achyranthes bidentata $\mathrm{Bl}$. & Juice \\
\hline 24 & Insomnia & Mentha spicata L. & Infusion \\
\hline 25 & $\begin{array}{l}\text { Intestinal } \\
\text { worms }\end{array}$ & $\begin{array}{l}\text { Taxus wallichiana Zucc., Morus } \\
\text { alba } \mathrm{L} .\end{array}$ & $\begin{array}{l}\text { Decoction, } \\
\text { juice }\end{array}$ \\
\hline
\end{tabular}

with lukewarm water to treat gastritis. The decoction extracted by boiling about 100 gm roots of $C$. pariera in $500 \mathrm{ml}$ of water for 15-20 minutes is drunk to get relief from gastritis. Half teaspoon of rhizome powder of C. long $a$ and salt mixed with $250 \mathrm{ml}$ of diluted curd is drunk in empty stomach for curing gastritis. The juice of D. cordata is drunk in empty stomach to cure gastritis. 50 gm fresh bark and fruits of E. officinalis and $50 \mathrm{gm}$ fresh bark of $M$. indica is boiled in three liters of water till the water volume become half, then filtered and the decoction thus prepared is mixed with 10-15 ml of urine of cow and drunk in empty stomach for the treatment of gastritis. Few seeds of $Z$. armatum are boiled in $250 \mathrm{ml}$ of water for $15-20$ minutes and the decoction is taken orally to cure gastritis; the root juice is also useful for it. One $\mathrm{kg}$ of bark and leaves of T. wallichiana is cooked in 10 liters of water for few hours until the water is reduced to half liter, thus formed two teaspoons of decoction is taken daily in empty stomach for gastritis. The root juice of $S$. amplexicaulis is used for gastritis. The fresh root of $R$. dentatus is chewed for sometimes which helps to cure the tooth gum swelling.

The seed paste of the L. neesiana is applied on the forehead to get relieve from headache.

The paste of the leaves of $F$. nubicola is applied on the affected area to treat herpes zoster.

The juice extracted from the roots is given for the treatment of in appetence due to evil eyes

Infusion of leaves of M. spicata that are kept overnight is drunk early morning in empty stomach along with the leaves for the treatment of insomnia.

One $\mathrm{kg}$ of bark and leaves of $T$.

wallichiana is cooked in 10 liters of water for few hours until the water is reduced to half liter, thus formed two teaspoons of decoction is taken daily in empty stomach to kill intestinal worms. One teaspoon of root juice of $M$. alba is taken twice a day 
Shubhechchha Thapa / Our Nature (2012) 10: 176-190

$\begin{array}{llll}26 & \text { Intoxicatio } & \text { Paris polyphylla } \text { Smith } & \text { Juice } \\ & & \\ 27 & \text { Jaundice } & \text { Cuscuta reflexa } \text { Roxb. } & \text { Juice }\end{array}$

28 Leucorrhea Curculingo orchioides Gaertn., Equisetum debile Roxb. ex Vaucher, Hibiscus lampas Cav.

29 Menstrual disorder

Citrus aurantifolia (Christ.) Swingle

30 Mouth ulcer

31 Over heat

Amaranthus spinosus L., Elettaria cardamomum (L.) Maton, Trigonella foenum-graceum L., Plantago major L., Musa paradisiaca $\mathrm{L}$.

32 Rheumatis $\mathrm{m}$

Urtica dioca L., Myrica esculenta Buch.-Ham. ex D. Don

33 Scabies
Artemesia indica Willd.,Ficus semicordata Buch.-Ham. ex Sm., Rubia manjith Roxb. Ex Fleming, Lyonia ovalifolia (Wall.) Drude that kills harmful intestinal worms.

Two teaspoons of rhizome juice of $P$. polyphylla is boiled in $300 \mathrm{ml}$ of cow milk and then drunk to get relief from intoxication.

The root juice of $C$. reflexa is taken thrice a day to cure jaundice; additionaly, the sun dried plant is spread under the bed of a patient until cured.

Infusion The overnight kept infusion from equal amount of crushed roots of $C$. orchioides, $H$. lampas and E. debile is drunk in empty stomach early morning for the treatment of leucorrhea.

Juice The mixture, formed by one teaspoon juice of $C$. aurantifolia and a pinch of $C$. longa along with one teaspoon of honey and two-three drops blood of black goat/rooster, is taken orally that also includes incantations by Dhami/Jhankri for curing the menstrual disorders.

Juice The filtrate or juice from crushed raw seeds of the plant is applied on the affected area to get relief from mouth ulcer.

Infusion, The roots of A. spinosus is crushed and juice soaked overnight in $500 \mathrm{ml}$ of water along with two-three pieces of fruits of $E$. cardamomum and drunk in empty stomach in early morning for curing over heat. The infusion of dried seeds of $T$.

foenum-graceum and $P$. major that are kept overnight is drunk in empty stomach relief from overheat. Juice from the root of $M$. paradisiaca is drunk for the treatment of overheat.

Cooked, The leaves of $U$. dioca are cooked and decoction taken daily for the treatment of rheumatism. Powder from about 300 gm of bark of M. esculenta is boiled in three liters of water till the water becomes half; the mixture is then filtered and again boiled with half liter of mustard oil for 25-30 minutes. Thus formed decoction is applied on the affected area with gentle massage to get relief from rheumatic pain.

Paste, juice The juice of leaves of $F$. semicordata is applied for curing scabies. The paste of $A$. indica (Leaf), the paster of $R$. manjith (whole plant) and the paste of $L$. ovalifolia (young shoots) is applied on the affected area for the treatment of scabies. 
Shubhechchha Thapa / Our Nature (2012) 10: 176-190

34 Sinusitis

Centella asiatica (L.) Urb., Drymaria cordata L.,

Tropaeolum majus L., Syzygium operculatum (Roxb.) Merril\&

Perry, Oxalis corniculata

L.,Justicia adhatoda L.
Allium sativum $\mathrm{L}$.

Euphorbia hirta L., Lyonia ovalifolia (Wall.) Drude, Lycopodium clavatum $\mathrm{L}$.

37 Stomach pain

Achyranthes bidentata $\mathrm{Bl}$., Don) DC. Rhus semialata Murray
Paste, powder, juice, decoction Solanum capsicoides All., Rumex dentatus L., Potentilla fulgens Wall. ex Hock

The paste made from $C$. asiatica and $D$. cordata is enclosed in banana leaf and heated for few minutes in the hot fire ashes, then wrapped in clean cloth by removing the leaf and smell it continuously for few minutes for the treatment of sinusitis. The leaves and flowers of $T$. majus are crushed and smelled that results sneezing which cures sinusitis;

additionally, the paste of leaves and flowers are applied around the nose. The powder of dried leaves as well as juice of bark of S. operculatum is taken orally for the treatment of sinusitis. The juice of the $O$. corniculata is used for sinusitis. The decoction prepared from slightly burned leaves of J. adhatoda is also used for the treatment of sinusitis.

Paste The paste of the bulb is applied for curing the skin boils

Raw, paste, The fresh latex of roots of E. hirta is juice applied in the skin burn for its fast recovery. The paste of young shoots of $L$. ovalifolia and the root juice of $L$. clavatum is applied on skin burn for the fast healing.

Juice, powder Inula cappa (Buch.-Ham. ex D.

Fragaria nubicola Lindl. ex Lacaita, Ocimum sanctum L.

Raw A teaspoon of crushed raw seed juice of $C$. zeylanicum is taken orally twice a day for stomach pain. Two teaspoons of root juice of I. cappa is taken orally during stomach pain. Two teaspoons of seed powder of $R$. semialata are taken with lukewarm water during stomach pain.

Raw fruits of $F$. nubicola are taken for tonsillitis. Three-five fresh leaves of $O$. sanctum are taken early morning without speaking to get relief from tonsillitis.

Raw, The raw stem of A. bidentata is used as smoke tooth brush for toothache. Smoke from dried or fresh fruits of $S$. capsicoides is employed inside mouth to get relieve from toothache, smoke also kills and drops the worms of the teeth. The fresh root of $R$. dentatus is chewed for sometimes which helps to relieve toothache. The root of $P$. fulgens is cut into small pieces and chewed to treat toothache. 
Shubhechchha Thapa / Our Nature (2012) 10: 176-190

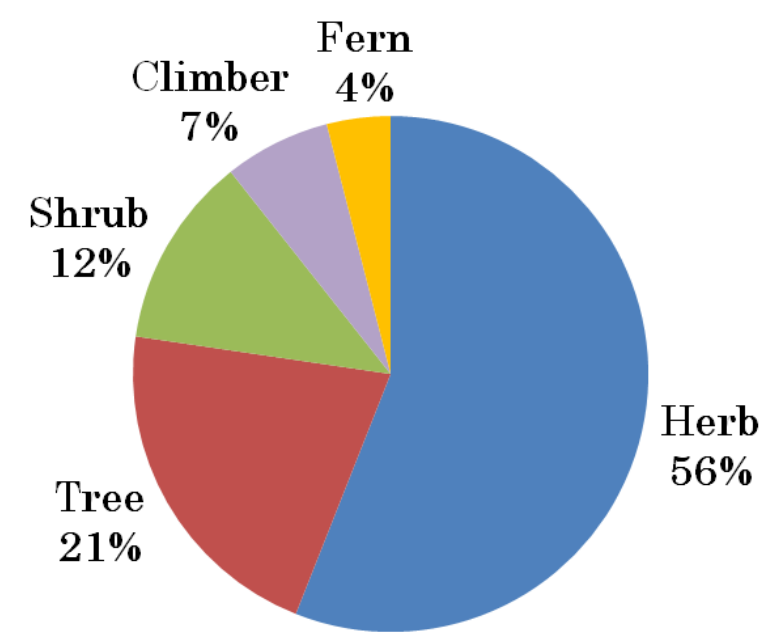

Figure 2. Habit wise distribution of medicinal plants

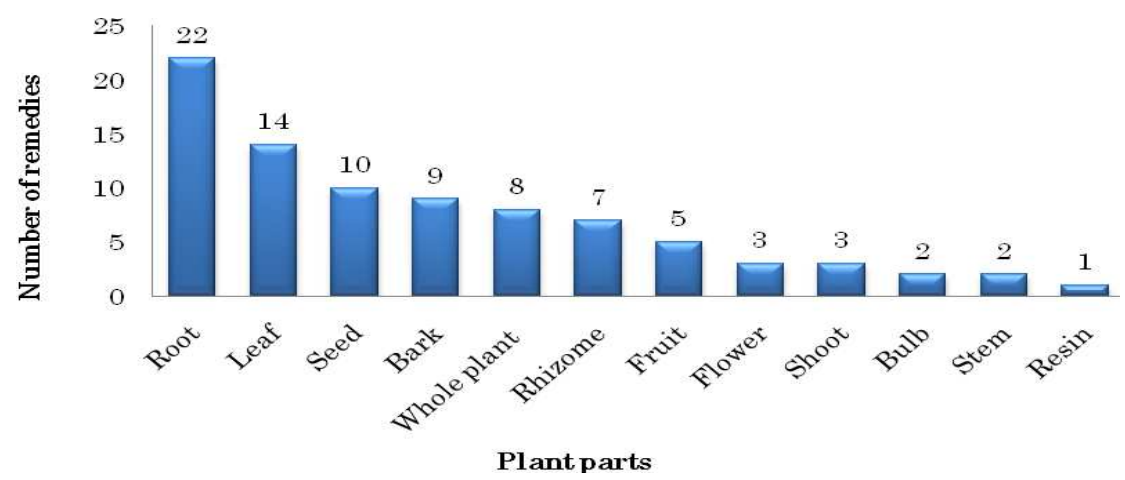

Figure 3. Number of remedies based on plant parts used

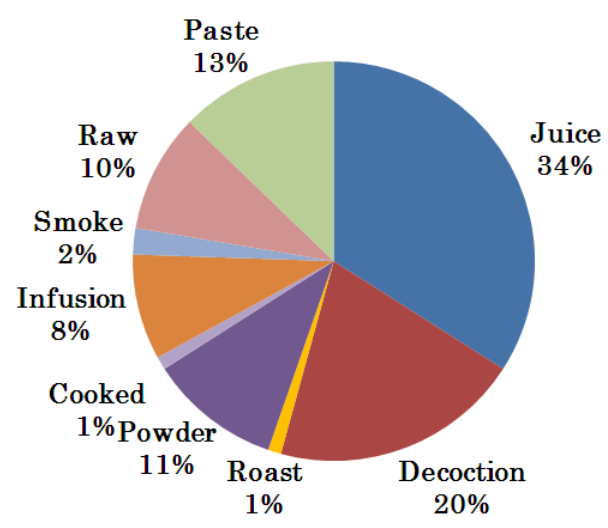

Figure 4. Plant species based on the form of medication 


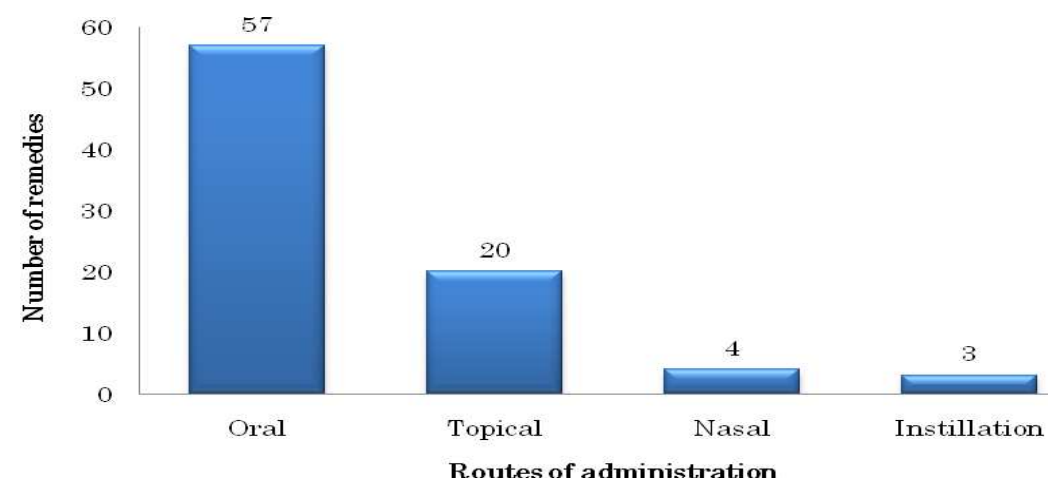

Figure 5. Number of remedies based on routes of administration

Manandhar (1995), Subedi (1998), Joshi and Joshi (2000) and Kunwar et al. (2010) reported the use of Potentilla fulgens in dental problems similar to the present finding. The flower of Woodfordia fruticosa was also reported to be used in curing dysentery by Manandhar (1990), Manandhar (1992), Acharya (1996), and Oli et al. (2005). Berberis asiatica and Mahonia napaulensis, used for opthalmological ailments, was also recorded by Subedi (1998), and Shrestha et al. (2004). The use of Rhododendron arboreum for fish bone prick and dysentery was also accounted by Subedi (1998) and Shrestha and Dhillion (2003). Similarly, the use of Ocimum sanctum for cough and cold, and Allium sativum for skin diseases was also documented by Rana et al. (2010) and Sen et al. (2011), respectively. Mala et al. (2012) also reported the use of Acorus calamus and Urtica dioica for cough and rheumatism, respectively.

\section{Knowledge and Rituals}

Local healers (Dhami/Jhankri) were the most popular one in the village for practicing folk medicine. Besides, the other knowledgeable groups, such as women and elders, also practice home remedy. According to the some local healers, they acquired the knowledge from their Guru (God) who taught them in dreams. Also during Jhankri basne (spiritual treatment) period, the healers identify the illness of their patient, and treat them accordingly that includes rituals such as incantations, amulets, magic, sacrifices, charms, and religious verses. Generally, the patients were examined in the morning or evening in particular days like Tuesday and Saturday.

The local healers collect the medicinal plants only when needed in certain days like Sunday, Tuesday and full moon day. Some of the healers believe that the medicinal plants of nearby home will not work since the plants are unpurified by domestic animals and people, which lead the lost of their healing properties. Thus, the forest becomes the main source of medicinal plants for them.

The traditional home remedy is much 
less in practice compared to the past few years because of the establishment of health post in the village as well as younger generation being less aware about the traditional medicines. There is also lack of hand over or sharing of knowledge from older to younger generation. Thus, the traditional healers as well as younger generation should be motivated to practice and conserve the traditional medicine, and such practices should be legalized. Furthermore, the plant species used in folk medicine should be subjected to biochemical analysis for their efficacy and verification.

\section{Acknowledgements}

Thanks are due to the Social Inclusion Research Fund-SNV Nepal for the financial support, Dr. Nanda Bahadur Singh for his valuable suggestions and guidance, and the local people of Salija for providing necessary information and cooperation.

\section{References}

Acharya, S.K. 1996. Folk uses of some medicinal plants of Pawannagar, Dang District. Journal of Natural History Museum 15: 25-35.

Baral, S.R. and P.P. Kurmi 2006. A compendium of medicinal plants in Nepal. Published by Rachana Sharma, Maiju Bahal, Kathmandu, Nepal. 281p.

Bhattarai, N.K. 1992. Medical ethnobotany in the Karnali Zone, Nepal. Economic Botany 46(3): 257-261.

Bhattarai, S., R.P. Chaudhary, C.L. Quave and R.S.L Taylor 2010. The use of medicinal plants in the trans-himalayan arid zone of Mustang district, Nepal. Journal of Ethnobiology and Ethnomedicine 6: 14.

Bista, D.B. 2004. People of Nepal. Ratna Pustak Bhandar, Kathmandu, Nepal.

CBS (Central Bureau of Statistics) 2001. Population Census. National Planning Commision (NPC), Kathmandu, Nepal.

Cheikhyoussef, A., M. Shapi, K. Matengu and H.M. Ashekele 2011. Ethnobotanical study of indigenous knowledge on medicinal plant use by traditional healers in Oshikoto region, Namibia. Journal of Ethnobiology and Ethnomedicine 7: 10.

Cox, P.A. and M.J. Ballick 1994. The ethnobotanical approach to drug discovery. Scientific America, June. pp. 32-87.

DDP 2004. District Development Profile of Nepal. A development database of Nepal. Publication Informal Sector Research and Study Centre, Kamaladi, Kathmandu, Nepal.

Gautam, R. and A.K. Thapa-Magar 1994. Tribal ethnography of Nepal. Volume II. Published by Delhi Book Faith, India. pp. 22-40.

Giday, M., Z. Asfaw, Z. Woldu and T. Teklehaymanot 2009. Medicinal plant knowledge of the Bench ethnic group of Ethiopia: an ethnobotanical investigation. Journal of Ethnobiology and Ethnomedicine 5: 34

Joshi, A.R. and K. Joshi 2000. Indigenous knowledge and uses of medicinal plants by local communities of the Kali Gandaki Watershed Area, Nepal. Journal of Ethnopharmacology 73: 175-183.

Kunwar, R.M., K.P. Shrestha and R.W. Bussmann 2010. Traditional herbal medicine in Far-west Nepal: a pharmacological appraisal. Journal of Ethnobiology and Ethnomedicine 6: 35.

Lawrence, G.H.M. 1967. Taxonomy of vascular plants. Oxford and IBH Publishing Co. Pvt. Ltd., New Delhi, India.

Lulekal, E., E. Kelbessa, T. Bekele and H. Yineger 2008. An ethnobotanical study of medicinal plants in Mana Angetu District, southeastern Ethiopia. Journal of Ethnobiology and Ethnomedicine 4: 10.

Magar, S.T. 2008. A report on indigenous knowledge on the utilization of medicinal plants in the Magar community: A case study of Salija VDC Parbat. Submitted to SNV Nepal, Bakhundole, Lalitpur, Kathmandu, Nepal, pp 13-15

Mala, F.A., M.A. Lone, F.A. Lone and N. Arya 2012. Ethno-medicinal survey of Kajinaag range of Kashmir Himalaya, India. International Journal of Pharma and Bio Sciences 3: 2.

Malla, S.B., A.B. Shrestha, S.B. Rajbhandari, T.B. Shrestha, P.M. Adhikari and S.R. Adhikari 1976. Flora of Langtang and Cross Section Vegetation Survey (Central Zone). Bulletin of Department of Medicinal Plants, Thapathali, Kathmandu, Nepal.

Manandhar, N.P. 1990. Traditional phytotherapy of Danuwar tribes of Kamlakhonj in Sindhuli district, Nepal. Fitoterapia 61(4): 325-331.

Manandhar, N.P. 1992. Folklore medicine of Dhading 
Shubhechchha Thapa / Our Nature (2012) 10: 176-190

district, Nepal. Fitoterapia 63(2): 163-177.

Manandhar, N.P. 1995. A survey of medicinal plants of Jajarkot District, Nepal. Journal of Ethnopharmacology 48: 1-6.

Mani, M.S. 1994. Himalayan Flowers: Introduction to incomparable gems of flowers of the Himalayan. Craftsman Press, Bangkok (Thailand).

Martin, G.J. 1995. Ethnobotany: A methods manual. Chapman and Halls, London, U.K.

Oli, B.R., S.K. Ghimire and D.R. Bhuju 2005. Ethnographic validity and uses of plants locally utilized in the Churiya of east Nepal: A quantitative approach to ethnobotany. Botanica Orientalis 5: 40-44.

Polunin, O. and A. Stainton 1984. Flowers of the Himalayan. Oxford University Press, Walton Street, Oxford.

Rana, M.P., M.S.I. Sohel, S. Akhter and M.J. Islam 2010. Ethno-medicinal plants use by the Manipuri tribal community in Bangladesh. Journal of Forestry Research 21: 85-92.

Sen, S., C. Raja, D. Biplab and N. Devanna 2011. An ethnobotanical survey of medicinal plants used by ethnic people in West and South district of Tripura India. Journal of Forestry Research 22(3): 417-426.

Shrestha, A., K.C. Bishnu and C.B. Thapa 2004. Ethnomedicinal uses of plants among the Kumal community in Chirtungdhara, Palpa, Nepal Botanica Orientalis 4(1): 59-62.

Shrestha, K.K., N.N. Tiwari and S.K. Ghimire 2000 MAPDON- Medicinal and Aromatic Plants Database of Nepal. In Proceedings of Nepal-Japan joint Symposium on Conservation and Utilization of Himalayan Medicinal Resource. HMG Nepal and SCDHMR. pp. 53-74.

Shrestha, P.M. and S.S. Dhillion 2003. Medicinal plant diversity and use in the highlands of Dolakha District, Nepal. Journal of Ethnopharmacology 86: 81-96.

Simbo, D.J. 2010. An ethnobotanical survey of medicinal plants in Babungo, Northwest Region, Cameroon. Journal of Ethnobiology and Ethnomedicine 6: 8 .

Subedi, B.P. 1998. Participatory utilization and conservation of medicinal and aromatic plants: A case from western Nepal Himalayan. Medicinal plants: A global heritage. In Proceedings of the International Conference on Medicinal Plants for Survival.

Tiwari, N.N. 1994. Wild relatives of cultivated medicinal and aromatic plants in Nepal. In Proceedings of National Conference on Wild Relatives of Cultivated Plants in Nepal. pp. 141-148. 